\title{
INTRASTATE SECURITIES TRANSACTIONS UNDER THE FEDERAL SECURITIES ACT
}

\author{
Daniel J. McCaulex, Jr. $\dagger$
}

\begin{abstract}
The exemption which the federal securities legislation provides for intrastate offerings is a narrow one, surrounded by complexities likely to entrap the intrastate issuer and his attorney in unsuspected violations. This article, one of many to be published in various law journals during the ensuing year by members of the Commission and its staff to mark the silver anniversary of the Commission's activities, alerts the reader to these problems by exploring the elements of the exemption and reviewing the legislative context, history and recent proposals. The author then discusses the applicability of the frand and civil liability provisions of the Securities Act to intrastate transactions and the implications of the parallel state securities regulation.
\end{abstract}

The Securities and Exchange Commission, in the administration of the several acts over which it has assumed full jurisdiction, ${ }^{1}$ often parallels in function the authority and responsibility of various state commissions and administrators, as well as other federal independent regulatory agencies. This is particularly so under the Securities Act of $1933,{ }^{2}$ which gives rise to problems with respect to intrastate offerings of securities, problems which it is the purpose of this article to explore. It is a misconception common among a great many issuers of securities and among attorneys who have had only a limited

† Member of Pennsylvania Bar. B.S., 1938, La Salle College; IL.B., 1941 University of Pennsylvania Law School. Associate General Counsel, Securities \& Exchange Comission. Formerly Special Deputy Attorney General of Pennsylvania and counsel to Pennsylvania Securities Commission.

The author acknowledges the research assistance of Melvin Katz, Esq., of the New York Bar and staff of the General Counsel's Office of the Commission, and of John Monk, a former Law Clerk on the Commission's Staff.

The Securities and Exchange Commission, as a matter of policy, disclaims responsibility for any private publication by any of its employees. The views expressed herein are those of the author and do not necessarily reflect the views of the Commission or of the author's colleagues upon the staff of the Commission.

1. E.g., the Securities Exchange Act of 1934, 48 Stat. 881, as amended, 15 U.S.C. $\$ \$ 78 \mathrm{a}-78 \mathrm{jj}$ (1952) (hereinafter referred to as the Exchange Act) ; the Securities Act of 1933 , 48 Stat. 74 , as amended, 15 U.S.C. $\$ \$ 77 a-77 a a$ (1952) (hereinafter referred to as the Securities Act). Furthermore, the Commission administers the Public Utility Holding Company Act of 1935, 49 Stat. 838, as amended, 15 U.S.C. $\$ \$ 79-79 z-6$ (1952); the Trust Indenture Act of 1939, 53 Stat. 1149, as amended, 15 U.S.C. $\S \S 77 a a a-77 b b b b(1952)$; the Investment Company Act of 1940, 54 Stat. 789, as amended, 15 U.S.C. $\$ \$ 80 a-1-80 a-52$ (1950); and the Investment Advisers Act of 1940, 54 Stat. 847, as amended, 15 U.S.C. $\$ \$ 80 \mathrm{~b}-1-80 \mathrm{~b}-21$ (1952). The Commission also performs an advisory function under Chapter $\mathrm{X}$ of the Bankruptcy Act, 52 Stat. $8 \$ 3$ (1938), as amended, 11 U.S.C. $\$ \$ 501-676$ (1952).

2. Considerable overlap of functions has also been involved in the Commission's administration of the Public Utility Holding Company Act of 1935, supra note 1. 
exposure, if any, to the Federal Securities Laws to assume that if securities are distributed intrastate there need be no concern whatsoever with the Commission and the Securities Act which it administers. Nothing could be further from the truth. As will be developed more fully, the intrastate issuer and his attorney must be aware constantly of the narrow exemption channel through which the issuer is drifting and must safeguard continuously against possible violation of the federal law, with all its attendant consequences and sanctions. These difficulties may not be perceptible to the unwitting adventurer into the intricate and complicated Securities Act itself. The venture becomes even more risky to him if he finds himself entangled in any of the many diverse, complex factual situations under corporate law which necessitate "administrative interpretation," particularly if he fails to take active advantage of this saving device. ${ }^{3}$

In the economic complex of today's capital markets, there are still many issuers of securities whose financial requirements are of modest proportions and who are desirous of raising venture capital within a reasonably small geographical area. Legitimate small business with such needs and motivations properly may question the necessity of entanglement with the federal law. On the other hand, some, often motivated by less legitimate purposes, may seek to utilize the intrastate exemption for the purpose of evading requirements of disclosure under the Securities Act. ${ }^{4}$ It is probably safe to conclude that in this, as well as in other areas, it is the unsavory tactics of the few which obtain more publicity than the proper activities of the many. Be that as it may, concern has developed in some circles with the result that legislators and others have raised as an issue the propriety of exempting intrastate securities transactions from the Securities Act: The leading congressional proponent of federal regulation of all securities transactions, Congressman Abraham Multer of New York, recently has been joined publicly in this view by J. Sinclair Armstrong, a former Chairman of the SEC.5

3. Since its inception the SEC has, as a service to industry and the bar, made available interpretive advice on complex or novel questions. To the newcomer the extent of the service may not be known, but to those who are active in the securities field this service is well known and frequently sought. Each of the Commission's three operational divisions as well as its seventeen regional and branch offices participate in this service. In addition the office of the General Counsel may be consulted. In unusual cases or those of first impression the Commission itself considers the interpretive problem. For a more detailed discussion see: Meeker, SEC Legal Assistance Avcilable to the General Practitioner, Prac. Law., Oct. 1957, p. 42.

4. "The essential purpose of the [Securities Act] is to protect investors by requiring publication of certain information concerning securities before offered for sale." A. C. Frost v. Coeur d'Alene Mines Corp., 312 U.S. 38, 40 (1941).

5. Congressman Multer's legislative proposal and Mr. Armstrong's views are discussed at text accompanying notes 57-64 infra. 
When such questions arise, it is appropriate to reappraise the situation and to take stock of the values on both sides of the argument. The present discussion will include a review of the legislative history of the intrastate exemption; an analysis of the statutory language; registration problems; recent statutory recommendations; the impact of the anti-fraud and civil liability sections of the federal law upon intrastate issuers; and a short discussion of state regulation of securities transactions.

\section{Legislative Context and Legislative History}

Originally, section 5(c) of the Securities Act provided an exemption for securities sold by issuers within a single state by use of the mails. ${ }^{6}$ About a year later the intrastate exemption was removed and incorporated into the exemptions set forth in section 3 (a) as paragraph (11) ${ }^{7}$ where it has remained until the present time. The only change which has been made in the statutory language occurred in 1954 when the exemption limitations were made applicable to offers as well as to sale of securities. ${ }^{8}$ Section 3(a) (11) now exempts from the registration and prospectus requirements of the act:

"Any security which is a part of an issue offered and sold only to persons resident within a single State or Territory, where the issuer of such security is a person resident and doing business within or, if a corporation, incorporated by and doing business within, such State or Territory." 9

It cannot be emphasized too strongly that this exemption is a limited one which applies only with respect to the registration requirements provided in section 5 of the Securities Act. ${ }^{10}$ The introductory

6. "The provisions of this section [\$5] relating to the use of the mails shall not apply to the sale of any security where the issue of which it is a part is sold only to persons resident within a single State or Territory, where the issuer of such securities is a person resident and doing business within, or, if a corporation, incorporated by and doing business within, such State or Territory." Securities Act of 1933, ch. 38, $\S 5(c), 48$ Stat. 77.

7. 48 Stat. 906 (1934), as amended, 15 U.S.C. \$77c(a) (11) (Supp. V, 1958).

8. 68 Stat. 684 (1954), 15 U.S.C. $\$ 77 c(a)$ (11) (Supp. V, 1958).

9. 48 Stat. 906 (1934), as amended, 15 U.S.C. $\$ 77 c(a)$ (11) (Supp. V, 1958). (Emphasis added.) Only the words "offered and" were added.

10. 48 Stat. 77, as amended, 15 U.S.C. $\$ 77 \mathrm{e}$ (Supp. V, 1958). In essence this section makes unlawful (1) any sale or delivery of any security unless a registration statement has been made effective by the Commission, and (2) anzy offer to sell or offer to buy any security unless a registration statement has been filed with the Commission.

Commission views with respect to some of the types of information which may or may not be published by an issuer prior to the effective date of a registration statement are stated in SEC Securities Act Release No. 3844 (October 8, 1957). See also SEC v. Arvida Corp., 169 F. Supp. 211 (S.D.N.Y. 1959). 
clause in section 3 puts the careful practitioner on notice that the exemptions from the subchapter set forth in section 3(a) may be subject to other sections of the act. ${ }^{11}$ Section 17 (c) specifically brings within its provisions any securities which have been sold in violation of its anti-fraud provisions even though the securities are otherwise exempted by section 3 from registration under the act. ${ }^{12}$ In addition, section $12(2)$, one of the civil liability provisions of the act, applies to all securities, including those exempt under section 3, except so-called governments and municipals. ${ }^{13}$ And section 18 of the Securities Act must also be considered in discussing the legislative context of the intrastate exemption, ${ }^{14}$ for in this section Congress expressly declared that the intervention of the federal government into securities regulation was not to be construed as a pre-emption of the field since the power and authority of the states to regulate securities and transactions in securities were specifically reserved..$^{15}$

The original congressional intent with respect to the intrastate exemption was that it exempt only "sales within a state of the entire issues of local issuers." 10 One of the principal stated purposes of the Securities Act was to make state control "more effective by preventing evasion of state security legislation by the device of selling in interstate or foreign commerce from outside the state"; ${ }^{17}$ in fact, the original House bill ${ }^{18}$ contained a provision which would have made this legisla-

11. Section 3(a) states as a preamble to the specific exemptions therein set forth: "Except as hereinafter expressly provided, the provisions of the subchapter shall not apply to any of the following classes of securities..$"$ See notes 12, 13 and 66 infra, and discussion in text accompanying notes $65-81$ infra.

12. 48 Stat. 84 (1933), 15 U.S.C. \&77q (1952). Discussion of litigation wherein the Commission has charged fraud with respect to intrastate offerings appears at text accompanying notes $65-81$ infra.

13. 48 Stat. 84 (1933), 15 U.S.C. $\$ 77 l(2)$ (Supp. V, 1958).

14. 48 Stat. 85 (1933), 15 U.S.C. $\& 77 \mathrm{r}$ (1952). The section provides: "Nothing in this subchapter shall affect the jurisdiction of the securities commission (or any agency or office performing like functions) of any State or Territory of the United States, or the District of Columbia, over any security or any person."

15. Since the Securities Act is a disclosure statute, the Commission avoids any decision with respect to the merits of the securities being offered. This is not the case in most states where qualification of a security may be refused for any of several reasons. As an example, the amount of commission being paid to the underwriter or members of the selling group is one of the most important considerations in qualifying a security for sale in the several states. For a full discussion of the standards applied by state administrators see Loss \& CoWETT, BLUE SKY LAW 67-79 (1958).

16. H.R. ReP. No. 85, 73d Cong., 1st Sess. 6 (1933).

17. Id. at 10. As to this evasion the Report states: "The wisdom of such an exertion of congressional power bases itself upon the uncontested fact that dealers in securities have cleverly organized their means of distributing securities so as to evade State blue-sky legislation by never entering the State. Such a policy does not interfere with legitimate business, but only by resort to such a policy can interstate commerce be closed to illegitimate business." Id. at 11 .

18. H.R. 5480, 73d Cong., 1st Sess. (1933). 
tion even more directly supportive of state legislation by prohibiting the sale of securities in interstate commerce within a state "where such sale would have been a violation of the laws [of the State] . . . if it had taken place wholly therein." 19 There was a strong minority report criticizing this provision because it (a) gave each state arbitrary control of the interstate sale of securities within its boundaries; (b) removed the federal government from its traditional function as arbiter between states in regulating interstate commerce; and (c) made the federal government responsible for enforcement of the various state laws. ${ }^{20}$ Apparently as a result of these criticisms, the provision was deleted.

Insofar as congressional intent is concerned, it is clear that the following conclusions may be drawn from the legislative history of the intrastate exemption:

1. Federal securities legislation was enacted, among other reasons, to supplement state regulation by closing the door to interstate transactions as to which state regulation was being frustrated;

2. Federal pre-emption of the field was not intended;

3. The intrastate exemption would be available for the securities issues of local issuers only; and

4. An intrastate distribution of securities, although exempt from the registration provisions would nevertheless be subject to its civil liability and anti-fraud provisions.

\section{The Elements of the Intrastate Exemption}

Difficult interpretive questions and problems arise under section 3 (a) (11) because of the several requirements which must be met to assure compliance with the conditions of the intrastate exemption. It is not our purpose to endeavor here to settle all of these questions. Rather it is to emphasize the types of problems which confront issuers when they choose not to register their securities but rather to rely upon the intrastate exemption. The following is a breakdown and discussion of the factors which make up the exemption.

19. H.R. Rep. No. 152, 73d Cong., 1st Sess. 27 (1933). See also: H.R. Rep. No. 85, sitpra note 16 , at 17 .

20. H.R. ReP. No. 85 , supra note 16 , at 27 . The minority characterized the provision as injecting a "destructive principle" and said it was a "vexatious" and "burdensome" handicap in administration of the proposed federal securities legislation. 


\section{Any Security Which Is Part of an Issue}

\section{(a) Any Security}

Of course it is not within the scope of this article to discuss the breadth of meaning which has been given to the word "security." There has been much litigation as to whether or not a particular specie of such "intricate merchandise" ${ }^{21}$ which is being sold to the public falls within the statutory definition. ${ }^{22}$ Aside from obvious, conventional instruments such as stocks, bonds, notes and debentures, the courts have held many varying contractual arrangements securities which, to the casual observer, might not appear to be securities. These investment contract arrangements run the gamut from cemetery lots to oyster bottom acreage and from rabbits and silver foxes to whisky bottling and sales contracts. ${ }^{23}$ Recently, the variable annuity was held to be an equity

21. H.R. REP. No. 85, supra note 16, at 8: "The rank and file of securities buyers who have hitherto bought blindly should be made aware that securities are intricate merchandise." For a discussion of the accomplishments of the act in effecting this purpose see McCorkick, Understanding the SeCurities ACT AND tHe S.E.C. 30005 (1948).

22. The term "security" is defined in $\$ 2(1)$ of the act, 48 Stat. 74 (1933), 15 U.S.C. $77 \mathrm{~b}(1)$ (1952), as "any note, stock, treasury stock, bond, debenture, evidence of indebtedness, certificate of interest or participation in any profit-sharing agreement, collateral-trust certificate, preorganization certificate or subscription, transferable share, investment contract, voting-trust certificate, certificate of deposit for a security, fractional undivided interest in oil, gas, or other mineral rights, or, in general, any interest or instrument commonly known as a 'security,' or any certificate of interest or participation in, temparary or interim certificate for, receipt for, guarantee of, or warrant or right to subscribe to or purchase, any of the foregoing."

23. The leading cases are SEC v. W. J. Howey Co., 328 U.S. 293 (1946), which involved the sale and subsequent management of a portion of an orchard, and SEC v. C. M. Joiner Leasing Corp., 320 U.S. 344 (1943), wherein oil leasehold interests were sold coupled with representations that the vendor would prove the productivity of the land by drilling an exploration well. Other instances of such contracts are referred to in the Joiner case, 320 U.S. at $352 \mathrm{n} .10$, as follows: "One's cemetery lot is not ordinarily thought of as an investment and is most certainly real estate. But when such interests become the subjects of speculation in connection with the cemetery enterprise, courts have held conveyances of these lots to be securities. Matter of Waldsteir, 160 Misc. 763, 291 N.Y.S. 697 ; Holloway v. Thompson, 42 N.E. $2 d 421$ (Ind App.). For other instances where purported sales of property have been held investment contracts' see Securities \& Exchange Comm'n v. Crude Oil Corp., 93 F.2d 844 (interest in oil royalties sold as bill of sale for specified number of barrels of oil); Securities \& Exchange Comm'n v. Tung Corporation, 32 F. Supp. 371; Securities $\mathcal{E}$ Exchange Comm'n v. Bailey, $41 \mathrm{~F}$. Supp. 647 (land bearing tung trees, to be developed by seller); Securities \& Exchange Comm'n v. Payne, 35 F. Supp. 873 (silver foxes); Prohaska v. Hemmer-Miller Development Co., 256 Ili. App. 331 (farm land, to be paid for with proceeds of crops raised by vendor) ; Kerst v. Nelson, 171 Minn. 191, 213 N.W. 904 (land to be cultivated as a vineyard by a third party); Stevens v. Liberty Packing Corp., 111 N.J. Eq. 61, 161 A. 193 (rabbits)." To these may be added Penfield Co. v. SEC, 143 F.2d 746 (9th Cir. 1944), cert. denied, 323 U.S. 768 (1944) (whiskey bottling and sales contract); Ascher v. United States, 143 F.2d 592 (6th Cir. 1944) (popcorn vending machines); United States v. Carter \& Co., 56 F. Supp. 311 (W.D. Ky. 1944) (whiskey bottling and sales contract); SEC v. Bourbon Sales Corp., 47 F. Supp. 70 (W.D. Ky. 1942) (whiskey bottling and sales contract); SEC v. Payne, 33 F. Supp. 988 (D. Mass. 1940) and 39 F. Supp. 434 (D. Mass. 1941) (shares in fishing boat); United States v. Brough, Civil No. 13707, W.D. Okla, July 8, 1941 (pecan orchids) ; SEC. v. Cultivated Oyster Farms Corp., 1 S.E.C. Judicial Decisions 1934-1939 672 (S.D. Fla. 1939) (oyster bottom acreage); State v. Robbins, 185 Minn. 202, 240 N.W. 456 (1932) (muskrats). 
interest in a portfolio of securities although it was clothed in the trappings of an insurance policy. ${ }^{24}$

\section{(b) Part of an Issue}

Neither the Securities Act nor any of the rules adopted thereunder define either an "issue" or "part of an issue" as the term appears in the intrastate exemption. However, it was held in Shaw v. United States, ${ }^{25}$ that the meaning of "issue," as used in section 3(a)(11), was not to be equated with the meaning of "issue" under the law of a particular state. In the Shaw case it was contended that each sale or exchange of originally issued shares of a common character was a separate issue within the meaning of section 3 (a)(11). The court rejected this contention. In so doing, it defined an "issue" as "all the shares of common character originally though successively issued by the corporation." 26 It seems clear that the court's definition goes far beyond the point necessary to reject the extremely narrow interpretation urged by the accused. Obviously, it would frustrate the registration provisions of the Securities Act if each individual sale of a security of a "common character" constituted an "issue." On the other hand, it has been pointed out that to interpret "issue" to mean all of the issued shares of a common character; even though successively issued, has the effect of making "issue" synonymous with "class." 27 Were this latter interpretation to be adopted, any interstate sale, however remote in time, would thereafter preclude forever the use of the intrastate exemption in the sale of securities of the same class by an issuer. This would burden both large and small companies, but particularly the latter..$^{28}$ In fact, the construction by the Shaw court, as a practical matter, leaves little or no meaning to the words "part of an issue," which appear in section $3(a)(11)$.

24. SEC v. Variable Annuity Life Ins. Co., 79 S. Ct. 618 (1959). See comment on district court decision in 106 U. PA. L. REv. 483 (1958).

25. 131 F.2d 476, 480 (9th Cir. 1942). This was a criminal prosecution for the sale of unregistered securities.

26. 131 F.2d at 480 .

27. Loss, Securtties Regutation 365 n.212 (1951).

28. An issuer might have sold some of its securities in the past to an out-of-state investor pursuant to the private offering exemption ( $\$ 4(1), 48$ Stat. 77 (1933), 15 U.S.C. \$77d(1) (Supp. V, 1958)) so that registration of the securities was unnecessary. It would be a burden on the issuer thereafter to take the position that the proper use of one statutory exemption necessarily precludes the use of an entirely different exemption with respect to securities of the same class. This, of course, is only if the transactions are not integrated. See text accompanying notes 28-32 infra. However, the literal interpretation of the Shaw case would appear to impel this conclusion. However, this is so only if the transactions are integrated. 
Integration of Sales of Securities

What constitutes an issue or a part of an issue of securities within the statutory language of the intrastate exemption, is closely related to the problem of "integration," the colloquial expression used by the industry and the Commission in discussing certain registration problems. For want of more precise definition, "integration" may be conceived as that relationship between separate offers and sales of securities by an issuer which is such as to constitute a single related or continuous distribution of such securities. Essentially a section 5 problem, integration may sometimes affect areas not related to the intrastate exemption; for example, in a particular case, it may relate to whether the regulation $A$ exemption under section $3(b)$ is available to an issuer. $^{29}$

Integration questions do not depend solely upon the class of securities being distributed, although certainly this is a factor to be considered. ${ }^{30}$ In determining whether integration is warranted, the Commission considers the following factors: (1) are the offerings part of a single plan of financing, (2) do the offerings involve issuance of the same class of securities, (3) are the offerings made at or about the same time, (4) is the same type of consideration to be received, and (5) are the offerings made for the same general purpose. If one or more of these factors is not present, all of the surrounding circumstances must be considered in order to evaluate what weight or importance should be given to the factors which are present. ${ }^{31}$

One example of an integrated distribution which the Commission recently noticed publicly is the Crowell-Collier financing of 1955 and 1956. In that instance, $\$ 3,000,000$ of convertible debentures were sold in 1955 and an additional $\$ 1,000,000$ of convertible debentures were sold at a premium at three separate 1956 settlements. All of the debentures were covered by the same trust indenture. The premium price charged in 1956 was related to the market price of the common stock into which the debentures were convertible. Even though the sales were a year apart, unquestionably the distribution was integrated..$^{32}$

If it is determined, on the basis of the aforementioned factors, that intrastate offers and sales of securities are so related to interstate offers

29. See note 51 infra and accompanying text.

30. For this reason the Commission does not follow the literal language of Shaw v. United States, supra note 24.

31. See Unity Gold Corp., 3 S.E.C. 618, 625 (1938).

32. See SEC Securities Act Release No. 3825 (Aug. 12, 1947) which stated: "It has been and is the Commission's position that an issuer or an underwriter may not separate parts of a series of related transactions comprising an issue of securities and thereby seek to establish that a particular part is a private transaction if the whole involves a public offering of the securities." 
and sales as to be integrated, those intrastate transactions to which section 3(a) (11) would otherwise have applied will not be exempt. Typical of the many situations in which the problem may arise are: (1) mergers and consolidations, (2) reissuance of treasury stock, (3) pre-organization subscriptions as distinguished from the underlying securities they represent, (4) securities offered by affiliated corporations, (5) private reorganizations of corporations, and (6) unit offerings of different securities. In view of the many factors which must be considered in such cases, the availability of the intrastate exemption must be determined on the facts of each particular case.

Related directly to "integration" is the problem resulting from the issuance of securities to corporate promoters. It is not uncommon for out-of-state promoters to form a corporation and to take down a bloc of stock for either services, property or cash. Thereafter, the corporation may decide to sell its own stock intrastate. If the question is approached by evaluating the "integration factors," it is likely that in many cases the result would be that there is no integration and that the intrastate public sale is proper under section 3(a)(11). If an offering to promoters of the same class of securities is at a different price, at a different (usually prior) time, and for a different purpose than the public offering, integration is questionable. On the other hand, offerings to out-of-state promoters, at or about the same time as the public offering, presents a different situation, and may be integrated so as to nullify the section $3(\mathrm{a})(11)$ exemption.

\section{Residence of Offeree, Purchaser, and Issuer}

The statutory language contemplates that all of the parties to an intrastate transaction must be residents of the same state.

\section{(a) Individual Person}

Whether an individual be an offeree or purchaser, the Commission has always interpreted residence as synonymous with domicile. The statutory basis for this interpretation is well grounded in the requirement that the entire issue of securities be sold in a single state. ${ }^{33}$ Necessarily, the residence of the offeree or purchaser should be bona fide. The SEC, or, where litigation is involved, a court, will look through a device or subterfuge which may have been used to give the appearance that the offeree or purchaser is a resident of the state. Thus, the residence requirement has been held not to have been satisfied

33. See H.R. REP. No. 85, supra note 16. See also SEC Securities Act Release No. 1459 (May 29, 1937). 
where stock certificates were placed in the name of actual residents for thirty days on the understanding that these persons later would transfer the securities to non-residents; ${ }^{34}$ where securities were transferred to a resident broker who later sold them to non-residents; ${ }^{35}$ and where the transfer was to a resident attorney representing non-residents. ${ }^{36}$

However, it is not reasonable to assume that a person who purchases securities in an intrastate offering will hold the securities forever. Therefore, a purchaser, whether he himself remains a resident or becomes in good faith a non-resident, may, after a reasonable time, sell his securities to a non-resident, and, in the absence of any inference of an intent to evade the registration requirements of the act, the exemption would not be lost by the issuer. ${ }^{37}$ Nor is an issuer in a position to insure against a legitimate change of residence by a stockholder. Consequently, such a change should not defeat the exemption-even though the purchaser is buying securities on the basis of a periodic or installment purchase plan. However, if the installments are to be paid over an extended period of time or if the contract is assignable, the issuer assumes a considerable risk that the exemption might be lost.

An obvious example of the residence problem arises with respect to armed forces personnel. ${ }^{38}$ The Commission always has examined very carefully the residence of military personnel who purchase securities sold under the intrastate exemption. Most frequently, servicemen temporarily assigned to a military installation have no intention of becoming residents of the state in which the facility is located. Since the Commission interprets residence in section $3(a)(11)$ as requiring domiciliary intent it is most likely that in the average case a sale to a serviceman would destroy the intrastate exemption, ${ }^{39}$ unless

34. SEC v. Hillsborough Investment Corp., Civil No. 1965, D.N.H., Dec. 11, 1958.

35. Stadia Oil \& Uranium Co. v. Wheelis, 251 F.2d 269 (10th Cir. 1957). The device of selling all of an issue of securities to a resident broker who then resold to non-residents was one of the first problems which confronted the Commission with respect to the intrastate exemption. See Brooklyn Manhattan Transit Corp., 1 S.E.C. 147 (1935) in which the Commission explains the reasons why it refused, on September 6,1934 , to register the bonds of the respondent on the New York Stock Exchange because of the use of the above-mentioned device.

36. FTC Securities Act Release No. 97 (December 28, 1933), which was issued by the Federal Trade Commission while it administered the Securities Act.

37. SEC Securities Act Release No. 1459 (May 29, 1937). The release contains the cautionary language, however, that: "If the securities were resold but a short time after their acquisition, this fact, although not conclusive, would strengthen the inference that their original purchase had not been for investment, and that the resale therefore constituted a part of a process of primary distribution; and a similar inference would naturally be created if the seller were a security dealer rather than a nonprofessional."

38. Unquestionably, servicemen are high on the list of those sought out by purveyors of unregistered securities.

39. Although there is no immediately apparent connection between the Federal Securities Act and the Pennsylvania Divorce Law, they have at least one thing in 
he was also, as a civilian, a resident of the state in which the securities were to be sold. Unquestionably, a serviceman may adopt a new "residence" in the domiciliary sense. However, there must be clear proof of his intent to abandon his former domicile. Since the average securities salesman has neither the time nor the inclination to investigate these niceties, issuers who seek to rely on the intrastate exemption would do well to avoid this possible legal pitfall. And it would appear that the foregoing is equally applicable to foreign nationals who reside in a state under a diplomatic or a temporary visitor's visa.

Residence problems may also arise in situations where nonresidents exercise options or warrants, pre-emptive rights, or rights as to convertible securities. The ramifications of such problems are manifold and whether the transaction would affect the intrastate exemption would necessarily depend upon the facts of each individual case. Consequently it is impossible to supply a rule of thumb which will cover the varied factual situations which could occur in any one or all of these situations. At the least, the issuer who is confronted with any of these problems must recognize that the intrastate exemption might be lost if care is not taken to assure that there is not in fact an offer or sale to a non-resident.

In determining whether or not the exemption may be safeguarded consideration must be given by the issuer to the following factors: (1) the time at which the now non-resident purchaser obtained an equitable interest in the security, (2) the possibility of obtaining a waiver by nonresident shareholders of rights which they might have with respect to the particular security, and, at all costs, (3) the absolute necessity of abstaining from the use of devices to evade the restrictions contained in the exemption. With respect to convertible securities and warrants, it might well be argued that a purchaser obtains such an equitable interest at the time of the original purchase of the security that the later exercise of the right should not affect the exemption. On the other hand, with respect to options and pre-emptive rights the suggestion that an equitable interest had accrued to the purchaser appears difficult to sustain. Clearly, an issuer, some of whose shareholders have become non-residents but who nevertheless are entitled to preemptive rights, cannot protect the exemption by arranging for a resident of the state to exercise the pre-emptive rights pursuant to a power-ofattorney given by non-resident shareholders. This would be evasion

common in that the jurisdiction and venue provision of the latter statute, PA. STAT. ANN. tit. 23, $\$ 16$ (1955), uses the term "bona fide resident" which has been interpreted to require domiciliary intent: Nixon v. Nixon, $329 \mathrm{~Pa} .256,198$ Atl. 154 (1938); McCauley v. McCauley, 184 Pa. Super. 361, 134 A.2d 684 (1957). 
of the principles controlling the exemption. The better course is to arrange, if possible, for a waiver of the pre-emptive right.

Conversely, inasmuch as the emphasis in the exemption is upon the residence of the person having the beneficial interest in the security, a direction by such person that the security be delivered and held for him outside the state has no effect on the issuer's exemption. ${ }^{40}$

\section{(b) Partnership}

In either a general or limited partnership it is a real possibility that some of the partners will not be residents of the same state as the issuer. The question then presented is whether the partnership, as a business entity, has a residence separate and distinct from its members. Since a general partner retains his personal identity in a partnership, to a degree, and has property rights with respect to the partnership property, it would seem that non-residence of such a general partner would seriously affect the issuer's intrastate exemption. On the other hand, in view of the restricted rights of limited partners with respect to partnership property and their interests in the entity, a stronger argument could be made that a purchase or sale by a limited partnership having non-resident limited partners would not necessarily defeat the exemption.

\section{(c) Trustee and Executor}

Transactions by either a trustee or an executor, whether in the purchase or sale of securities, raise substantial problems for any issuer who relies on the intrastate exemption. It appears clear that if a trustee, who is a resident of a particular state, offers and sells trust certificates in an irrevocable trust only to residents of that state, the transactions would be exempt from registration under section 3(a) (11). However, aside from this specific situation, the application of the law necessarily depends on the facts of the case involved, and no generalization is warranted with respect to the availability or nonavailability of the exemption.

\section{(d) Corporations}

Whether a corporation is the purchaser or the seller of securities, to preserve the intrastate exemption the corporation must make the purchase or the sale, respectively, in the state wherein it is incorpo-

40. SEC Securities Act Release No. 1459 (May 29, 1937). 
rated. ${ }^{41}$ Further, if the corporation is the issuer of securities (i.e., the seller) it must also "do business" within the state wherein the securities are being sold.

It is common practice for a corporation to obtain its charter in one state, although the principals, who are doing business in a corporate form, intend to conduct the corporation's principal business elsewhere than in the state of incorporation. ${ }^{42}$ It is hardly consistent with the language of the intrastate exemption that such a corporation, which may be registered to do business in several states, could participate under section 3 (a) (11) as a resident purchaser of securities which may be issued in several, or even one of the states in which the corporation is registered to do business. Although such a corporation may subject itself to an action at law, the payment of taxes, and other legal consequences in every state in which it registers to do business and, for the purpose of venue statutes, be considered a resident of each such state, nevertheless, such an interpretation of residence if applied with respect to the intrastate exemption would be inconsistent with the language of section $3(\mathrm{a})$ (11) and its legislative history.

\section{Multi-State Corporate Structure}

If a corporate entity cannot cross state lines-register to do business as a foreign corporation and offer or sell securities within that state-without loss of the intrastate exemption, should it then be able to do indirectly what it could not do directly? If a corporation were to set up subsidiaries or affiliates in several states, planning to finance the separate but related corporations through intrastate offerings in each state, the Commission could be expected to see through and to take a dim view of the plan. To preclude such multi-state corporate arrangement would be a logical extension of the consistently recognized interpretation of the exemption which has precluded a non-resident controlling shareholder, whether an individual or a corporation, selling control stock in the state of the issuer's incorporation.

41. It would seem that this principle follows from the plain language of $\$ 3(a)$ (11). A recent case which might be interpreted to have misconceived the statutory language in $\$ 3(\mathrm{a})(11)$ is Stadia Oil \& Uranium Co. v. Wheelis, 251 F.2d 269 (10th Cir. 1957). This was a civil action between private parties under the Securities Act. The SEC did not intervene or participate in the case amicus curiae. The issuer was a Nevada corporation which had registered to do business in Utah. Corporate securities were eventually distributed to residents of California through the device of using a "conduit sale" to a Utah broker. In the opinion there is a reference to $\S 3$ (a) (11) in discussion of the procedure used by the issuer in its attempt to evade registration. The decision rests on an interpretation of "dealer's transactions" exempt under $\$ 4$ of the Securities Act. On the facts of this case the corporate issuer could not have availed itself of the intrastate exemption. To have complied with $\S 3$ (a) (11) the Nevada corporation could only have issued its securities in Nevada.

42. There is no securities law in Delaware, where so many corporations are chartered which, in fact, never intend to do any business at all within the state. 


\section{Doing Business}

The requirement of "doing business" within the state is one which rests upon the issuer of securities regardless of whether the issuer is an individual, a corporation, or other type of business entity. A realistic interpretation of the statute could hardly require that the issuer do one hundred per cent of its business within the state in which it desires to issue securities under section 3(a)(11). On the other hand, the basic policy of the statute requires substantially more in the way of "doing business" than has been held by the courts to be sufficient for subjecting an individual or a business entity to service of process in in civil litigation. ${ }^{43}$

It is impossible to say that any specified percentage of an issuer's business, whether considered dollar-wise or by some other formula, must be performed by the issuer in the state of residence. The Commission's view over the years is that the issuer must conduct its principal business within the state.

A recent case on this point is SEC $v$. Truckee Showboat, Inc. ${ }^{44}$ The defendant was a California corporation which owned a wholesale pharmaceutical business in San Francisco, the assets of which were less than $\$ 13,000$. It kept its books and records in California and all of its officers and directors were residents of that State. It advertised for sale in California 4,080 shares of stock at $\$ 1,000$ per share. The proceeds less sales commissions were to be used to acquire, refurbish and operate the El Cortez Hotel in Las Vegas, Nevada. No sale of shares were made. The court held that the offer was in violation of the registration provisions of the act, ${ }^{45}$ and that under the factual circumstances of the case the intrastate exemption was not available to the defendant.

In the Truckee Shoreboat case the contemplated principal business of the issuer was outside the state of incorporation and for this reason the exemption was unavailable. Equally significant is that the court found a violation of the act even though only an offer had been made and no sales of securities had occurred.

43. The leading case is International Shoe Company v. Washington, 326 U.S. 310, 315-16 (1945). This case utilized the venue doctrine of forum non conveniens, the ultimate result of chipping away at the "mere solicitation" doctrine of which Green v. Chicago B. \& O. Ry., 205 U.S. 530 (1907), was the keystone. This had occurred through a series of cases wherein "solicitation plus" was, in varying factual situations, found to be sufficient to subject a non-resident to suit at law. The basic notion in the transition was that the non-resident should have "certain minimum contacts" with the forum so that suit there did not offend "traditional notions of fair play and substantial justice." Milliken v. Meyer, 311 U.S. 457, 463 (1940). See McGee v. International Life Ins. Co., 355 U.S. 220 (1957).

44. 157 F. Supp. 824 (S.D. Calif. 1957).

45. In view of certain facts, including the termination of the option to purchase the hotel, and undertakings by counsel for the issuer, the court found it unnecessary to exercise its equitable power to issue a preliminary injunction. 


\section{Offer and Sale}

This particular aspect of the exemption more properly might have been discussed earlier. However, the Truckee Showboat case in particular points out that there need not be a sale for a violation of the act to occur. An offer alone, under improper circumstances, may constitute a violation.

With the many high powered communication facilities available to an issuer from Main Street as well as one from Wall Street, care must be taken, when making an intrastate offering of securities, to limit the offering only to residents of the state in which the issue is being sold. Since newspapers use the mails, as well as interstate facilities, and since many, if not most, radio and television stations have a multi-state coverage, even inadvertance in the use of such facilities may destroy the exemption. At least in a newspaper announcement the issuer should state unequivocally that offers to purchase are solicited only from, and that sales of securities will be made only to, bona fide residents of the particular state involved. ${ }^{48}$ Such restrictions should also be woven into offerings by television and radio.

\section{The Burden of Meeting the Conditions of the Exemption Is on the Issuer}

The Securities Act is a remedial statute, and "the terms of an exception . . . must be 'strictly construed' against the claimant of its benefits." 47 In view of the remedial nature of the act, it has been held to be fair and reasonable to impose on an issuer, if he claims to have acted pursuant to an exemption, the burden of proof that the exemption in fact exists. ${ }^{48}$

In recognition of these burdens, some intrastate issuers have endeavored to protect themselves by obtaining a form of written assurance from the purchaser that he is a bona fide resident of the state in question. Similar assurances have been obtained by issuers in the form of letters of "investment intent" in transactions involving the private

46. SEC Securities Act Release No. 1459 (May 29, 1937).

47. SEC v. Sunbeam Gold Mines Co., 95 F.2d 699, 701 (9th Cir. 1938). See also: SEC v. C. M. Joiner Leasing Corp., 320 U.S. 344, 353, 355 (1943) ; Detroit Edison Co. v. SEC, 119 F.2d 730 (6th Cir. 1941).

48. SEC v. Ralston Purina Co., 346 U.S. 119, 126 (1953); SEC v. Sumbeam Gold Mine Co., 95 F.2d 699 (9th Cir. 1938). Cf. Schlemmer v. Buffalo R. \& P. Ry., 205 U.S. 1 (1907) ; Hartford Gas Co. v. SEC, 129 F.2d 794 (2d Cir. 1942) ; Electric Bond \& Share Co. v. SEC, 92 F.2d 580 (2d Cir. 1937), aff'd, 303 U.S. 419 (1938).

Although these principles have been announced in cases involving exemptions other than the intrastate exemption, there is no basis for distinguishing the applicable rules. Consequently, in order to preserve the exemption from registration, the issuer must channel his course most carefully through the varied pitfalis that confront him. 
offering exemption under section $4(1)$ of the act. The Commission recently has informed the industry and the bar, in a public release following the Crowell-Collier investigation, that an issuer relies upon such investment representations at his peril. ${ }^{49}$ The principles enunciated in that release are likewise applicable to residence representations under section 3(a) (11).

It may also be considered whether an issuer who inadvertently permits a few offers or sales to non-residents is thereafter precluded from utilizing the exemption. Since such an exemptive provision is to be strictly construed, it is the type of situation where the issuer may not be "a little pregnant." Administratively, the Commission has always taken the position that one sale to a non-resident destroys the exemption. Although there is no federal court case in which the Commission has sought injunctive relief where only one interstate offer or sale has occurred, there has been one administrative proceeding in which the Commission held that a single interstate sale nullified the exemption under section $3(\mathrm{a})(11)$. $^{50}$

\section{Effects of Failure To Meet the Exemption}

If an issuer of securities intrastate fails to comply, for one reason or another, with all of the conditions of the intrastate exemption, it may be that the securities will have to be registered pursuant to section 5 of the act. This will depend upon the dollar amount of the securities issued. If that amount does not exceed $\$ 300,000$ in any one year, regulation $A$ may be available ${ }^{51}$ its availability will present interpretive problems, however, and each case, necessarily will depend upon its own facts.

Where the conditions of the intrastate exemption have been violated, the Commission may sue to restrain any further violation by the issuer, ${ }^{52}$ and it is no defense to claim that the out-of-state sales

49. SEC Securities Act Release No. 3825. (August 12, 1957).

50. Professional Investors, Inc., 37 S.E.C. 173 (1956). The denial of registration in this case was not predicated solely upon the violation of $\$ 3(a)(11)$.

51. The Commission enacted regulation $A$ which exempts securities meeting specified conditions from the registration provisions of the act, pursuant to its rule-making power under $\$ 3(\mathrm{~b}), 48$ Stat. 76 (1933), as amended, 15 U.S.C. $\$ 77 \mathrm{c}$ (b) (Supp. V 1958). The regulation is 17 C.F.R. 230.251 (1949). Legislation has been proposed in the 86th Congress to increase the ceiling from $\$ 300,000$ to $\$ 500,000$. In fact a bill was approved in the Senate in the 85th Congress but was not acted upon by the House. Pending bills in the first session of the 86th Congress include: S. 1178; H.R. 4568; H.R. 2488; H.R. 5001. The Commission supports these proposals.

52. SEC v. Hillsborough Investment Corp., Civil No. 1965, D.N.H., Dec. 11, 1958; SEC v. Truckee Showboat, Inc., supra note 44; SEC v. Doctors Motels Inc., Civil No. KC 907, D.C. Kan., Feb. 11, 1958; SEC v. Hunt, Civil No. 1480, W.D. Wash., Feb. 18, 1946. 
have terminated. ${ }^{53}$ Furthermore, if such activities persist after the entry of an injunctive decree, the issuer may be charged with criminal contempt. ${ }^{54}$

Registered broker-dealers who engage in purportedly intrastate activities which result in a violation of the act are, of course, subject to possible administrative sanction. ${ }^{55} \mathrm{Or}$, an application for registration as a broker-dealer may on account of such a violation, if coupled with others, be denied. ${ }^{\text {"6 }}$

\section{Recent Legislative Proposals}

On February 27, 1958, the Honorable Abraham Multer introduced in the House a bill ${ }^{57}$ which would have eliminated the intrastate exemption from the Securities Act. ${ }^{58}$ The bill made no reference to section 18 of the Securities Act which preserves state regulatory power over securities transactions. Owing to the contemporaneous engagement of the senior members of the House Committee on Interstate and Foreign Commerce in more pressing matters before the Subcommittee on Legislative Oversight, neither this nor any other legislative proposals to amend the securities laws were considered by the Committee; nor was Mr. Multer's proposal introduced in the Senate during the 85th Congress. But as early as January 7, 1959, Mr. Multer reintroduced his House proposal in the 86 th Congress. ${ }^{59}$ No similar proposal has yet been introduced in the Senate.

On January 15, 1959, another bill to amend the Securities Act, containing interesting features with respect to the intrastate and other exemptions, was introduced in the House of Representatives. ${ }^{60}$ As it

53. SEC v. Doctors Motels Inc., supra note 52. This action was terminated later, however, by stipulation upon the issuer's registration of its securities.

54. Paul John Hunt, Civil No. 1560, W.D. Wash., Aug. 12, 1946.

55. Cf. J. A. Hogle \& Co., 36 S.E.C. 460 (1955). Here the Commission did not impose a sanction for reasons stated in its opinion, although it found that no exemption existed under $\$ 3(a)(11)$.

56. Professional Investors, Inc., 37 S.E.C. 173 (1956); Whitehall Corp., SEC Securities Exchange Act Release No. 5667 (April 2, 1958).

57. H.R. 11050, 85th Cong., 2d Sess. (1958).

58. The bill provided: "That Section 3(a) of the Securities Act of 1933 is amended by striking out the semicolon at the end of paragraph (10) and inserting a period in lieu thereof, and by striking out paragraph (11) thereof."

For a short, but emphatic, statement by Congressman Multer in support of his proposal, see 104 Cong. REc. A-1858 (daily ed. Feb. 27, 1958).

59. H.R. 884, 86th Cong., 1st Sess. (1959). The proposal was not accompanied by any supporting statement.

60. H.R. 2488, 86th Cong., 1st Sess. (1959). The proposal, which also covered other aspects of the Securities Act, originated with the Commission. It provides for the shifting of certain so-called transaction exemptions from $\$ 3(a)$ to $\$ 4$ of the act. The current $\S \S 3(a)(9),(10)$, and (11), frequently referred to as transaction exemptions rather than securities exemptions, in fact properly belong in $\$ 4$. A similar shift of these same exemptions was considered by the House of Representatives in 
relates to the intrastate exemption, the bill has two significant aspects. First, in the proposed new section 4(a) (5), the intrastate exemption is reworded as follows:

"Any offer or sale of a security which is part of an issue offered and sold exclusively to persons resident within a single State or Territory, where the issuer of such security is a person conducting his principal business operations within such State or Territory and resides in (or, if a corporation, is incorporated by) such State or Territory." 61

Second, there would be a new section 4(b) which would empower the Commission to "impose such terms and conditions . . . as may be necessary in the public interest and for the protection of investors," with respect to the intrastate exemption, the private offering exemption, and certain other transaction exemptions. ${ }^{62}$

The rule-making power in the bill is of more far-reaching import than the rewording of the statutory language of section 3(a)(11). The latter would merely incorporate a well-established SEC interpretation into the act. The former would authorize the Commission to make ground rules, not only for intrastate offerings, but for private placements and certain exchanges of securities. ${ }^{63}$ However, in view of the fact that the Commission has now submitted proposals which have been introduced in both houses of Congress and which omit this rule-making power, it is doubtful that extensive consideration will be given by Congress to the rule-making proposal. ${ }^{64}$

1941, along with other amendatory proposals. Although extended conferences and hearings took place the proposals were lost in the shuffle with the advent of World War II, and were neither acted upon then nor submitted in the years which have intervened. In the form in which the shift from one section to another was then proposed the significance was merely "technical." See SECurITIES AND ExcHange Commission, 77th Cong., Ist Sess., Report on Proposals for Amendment of tere Securities Act of 1933 and the Securities Act of 193424 (Comm. Print 1941).

61. H.R. 2488, supra note 60. (Emphasis added.) The emphasized words are the proposed changes. The proposal would substitute the word "exclusively" for the word "only." The words "conducting his principal business operations," as substitutes for the words "doing business," would merely codify the heretofore established Commission interpretation of "doing business." Cf. SEC v. Truckee Showboat Inc., 157 F. Supp. 824 (S.D. Calif. 1957).

62. H.R. 2488 , supra note 60 .

63. It is interesting to note that the Subcommittee on Legislative Oversight recommended that the private offering exemption should be conditioned upon either (1) an opinion by the Commission or (2) a "no action" letter from the Commission. See H.R. RER. No. 2711, 85th Cong., 2d Sess., 12 (1958).

64. S. 1178, H.R. 5001, 86th Cong., 1st Sess. (1959). These proposals also omit the rewording of $\S 3(\mathrm{a})(11)$, as quoted above, and the proposed shift of exemptions from $\$ 3$ to $\S 4$. 


\section{Applicability of Fraud and Civil Liability Provisions of Securities Act to Intrastate Transactions}

\section{Fraud in Intrastate Transactions}

Section 17 (c) of the Securities Act makes the anti-fraud provisions of that statute applicable to securities offered and sold within a single state. $^{65}$ The provision is applicable, however, only if the issuer, in the sale of securities, utilizes the requisite jurisdictional means, i.e., the mails or any means or instruments of transportation or communication in interstate commerce. The anti-fraud provisions of the statute are set forth in section 17(a) thereof and include: (1) the employment of any device, scheme, or artifice to defraud, (2) any misstatement of a material fact or an omission to state a material fact necessary to be stated under the circumstances, and (3) any transaction, practice, or course of business which operates as a fraud or deceit upon the purchaser. $^{66}$ There are numerous decisions, both criminal and civil, applying section 17 (a) to particular factual situations. ${ }^{67}$ Under

65. 48 Stat. 84 (1933), 15 U.S.C. \& 77q(c) (1952).

66. These anti-fraud provisions of the Securities Act have been embodied in rule 10B-5, 17 C.F.R 240.10b5 (1949), enacted pursuant to the Exchange Act $\$ 10$, 48 Stat. 891 (1934), as amended, 15 U.S.C. 78i (Supp. V, 1958). The effect of the rule is to apply the anti-fraud provisions to purchases of securities as well as to sales. It is hardly conceivable that an argument would ever be made to the effect that $\$ 3(a)(11)$ affords any exemption with respect to this Exchange Act rule. Since the intrastate exemption applies only to the registration provisions of the Securities Act it can have no application to the Exchange Act. Also the factual situations in at least two cases, where rule $10 \mathrm{~B}-5$ was applied, clearly demonstrate the implausibility of such an argument. See Northern Trust Co. v. Essaness Theaters Corp., 103 F. Supp. 954 (N.D. Ill. 1952) which involved local business; and Kardon v. National Gypsum Co., 69 F. Supp. 512 (E.D. Pa. 1946), 73 F. Supp. 798 (E.D. Pa. 1947), 83 F. Supp. 613 (E.D. $\mathrm{Pa} .1947$ ), which involved the purchase of a corporation owned by four individuals.

67. There have been many leading appellate cases in the fraud area. Examples of some of the many criminal prosecutions for fraud under the Securities Act are: United States v. Tellier, 255 F.2d 441 (2d Cir.), cert. denied, 358 U.S. 821 (1958); United States v. Vasen, 222 F.2d 3 (7th Cir.), cert. denied, 350 U.S. 834 (1955); Nemec v. United States 178 F.2d 656 (7th Cir. 1949), cert. denied, 339 U.S. 985 (1950); Kaufman v. United States, 163 F.2d 404 (5th Cir. 1947), cert. denied, 333 U.S. 857 (1948); Mansfield v. United States, 155 F.2d 952 (5th Cir.), cert deried, 329 U.S. 792 (1946) ; United States v. Monjar, 147 F.2d 916 (3d Cir. 1944), cert. denied, 325 U.S. 859 (1945); Harper v. United States, 143 F.2d 795 (8th Cir. 1944); Holmes v. United States, 134 F.2d 125 (8th Cir.), cert. denied, 319 U.S. 776 (1943); Gates v. United States, 122 F.2d 571 (10th Cir. 1941), cert. denied, 314 U.S. 698 (1942) ; Simons v. United States, 119 F.2d 539 (9th Cir.), cert. denied, 314 U.S. 616 (1941); Landay v. United States, 108 F.2d 698 (6th Cir. 1939), cert. denied, 309 U.S. 681 (1940); Kopald-Quinn \& Co. v. United States, 101 F.2d 628 (5th Cir.), cert. denied, 307 U.S. 628 (1939) ; Troutman v. United States, 100 F.2d 628 (10th Cir.), cert. denied, 306 U.S. 649 (1939); Bogy v. United States, 96 F.2d 734 (6th Cir.), cert. denied, 305 U.S. 608 (1938); Jarvis v. United States, 90 F.2d 243 (1st Cir.), cert. denied, 302 U.S. 705 (1937) ; Coplin v. United States, 88 F.2d 652 (9th Cir.), cert. denied, 301 U.S. 703 (1937).

Cases where the S.E.C. has succeeded in obtaining injunctions for violations of $\$ 17$ (a) of the Securities Act include SEC v. Thomasson Panhandle Co., 145 F.2d 408 (10th Cir. 1944); Timetrust v. SEC, 142 F.2d 744 (9th Cir. 1944); Otis \& Co. v. 
section $17(b)$ of the act the publication or circulation of certain types of sales material for the preparation of which the issuer has paid a consideration, is declared a fraudulent practice unless the payment of such consideration is disclosed; ${ }^{88}$ this provision, too, extends to issuers and underwriters who sell securities under the intrastate exemption.

In view of the clear application of the section 17 anti-fraud provisions to intrastate transactions, the section 3(a) (11) exemption from registration is not a license to omit disclosure of material facts which under all the circumstances would have to be disclosed to purchasers if the securities were being offered and sold interstate. An issuer who decides to take advantage of the intrastate exemption assumes the risk that he may violate the anti-fraud provisions of the statute. Thus, the burden is on the issuer to safeguard against the omission of material facts. If the Commission were to charge an issuer with a violation of the anti-fraud provisions of the act, a subsequent registration of the securities by the issuer would not eradicate the fraudulent misconduct. Doubtless the Commission would press for injunctive relief against such an issuer, even though, under all of the circumstances, it might determine not to refer the evidence for possible criminal prosecution.

Since under the Federal Rules of Civil Procedure it is not necessary to set forth in a complaint the underlying factual basis thereof, as it is in those states which still adhere to a fact-pleading procedure, the writer has been unable to determine precisely the number of injunctive actions brought by the Commission for violations of the act's antifraud provisions where securities were sold intrastate. From an extensive examination of some 225 legal actions which the Commission instituted for violation of section 17 (a) and $17(\mathrm{~b})$, it appears that substantially less than ten per cent of the actions brought under these provisions involved intrastate transactions. ${ }^{69}$ It does not appear that any intrastate fraud actions were instituted between 1940 and 1950. However, the emphasis which the Commission has recently placed upon enforcement litigation has brought an increase in the number of intra-

SEC, 106 F.2d 579 (6th Cir. 1939) ; SEC v. Universal Service Ass'n, 106 F.2d 232 (7th Cir. 1939), cert. denied, 308 U.S. 622 (1940).

Instances of violations of $\$ 17$ (a) by broker-dealers were involved in: Norris \& Hirshberg, Inc. v. SEC, 177 F.2d 228 (D.C. Cir. 1949); Hughes v. SEC, 174 F.2d 969 (D.C. Cir. 1949); Charles Hughes \& Co. v. SEC, 137 F.2d 434 (2d Cir. 1943), cert. denied, 321 U.S. 786 (1944); Archer v. SEC, 133 F.2d 795 (8th Cir.), cert. denied, 319 U.S. 767 (1943).

68. Professional Investors, Inc., 37 S.E.C. 173 (1956).

69. Since any statistical formula may tend to mislead, the writer desires to make it abundantly clear that no conclusions safely can be drawn therefrom. No attempt was made to compare, for example, the number of fraud cases where there had been a prior registration of the security with the number where no registration statement had been made effective. Neither does this review reflect the cases instituted for violation of the registration provisions of $\S 5$. 
state fraud cases as well as in other types of fraud actions. Only one of these cases, SEC v. Timetrust Inc. ${ }^{70}$ has been reported. The remaining intrastate fraud cases resulted in the entry of unreported consent decrees. ${ }^{71}$

Typical of the cases in which the Commission has taken action to enjoin intrastate sales which have been made in violation of section 17 is SEC v. Evergreen Memorial Park Ass'n ${ }^{72}$ In that case the association had, upon previous Commission action, been enjoined from the sale of investment contracts involving cemetery lots which had not been registered with the Commission. The court's decree, entered upon consent by the association, ${ }^{73}$ required the association, inter alia, to sell the investment lots for the individuals on a prescribed formula, to make up substantial delinquencies in the perpetual care fund, and to keep adequate and accurate books and records. While the Commission was investigating the extent of compliance with this prior decree, Evergreen gave notice to the Pennsylvania Securities Commission of its intention to sell debt securities intrastate in the amount of $\$ 100,000$. As a result of advertising in various newspapers within the State of Pennsylvania the association succeeded in disposing of the full amount. Following this successful sale, Evergreen gave notice to the Pennsylvania Securities Commission that, pursuant to an exemptive provision of the Pennsylvania statute, it intended to sell an additional $\$ 200,000$ of debentures intrastate. Prospective purchasers, as well as actual purchasers, were given a brochure, titled an "offering circular," which contained pictures of certain improved portions of the cemetery property and, among other things, an appraisal of the cemetery showing its value to be in excess of $\$ 8,700,000$. Aside from such untrue statements as appeared in the brochure or which were made orally in talking to offerees, the principal violations were omissions to state certain material facts in the brochure. ${ }^{74}$ Before any substantial amount of the

70. 28 F. Supp. 34 (N.D. Cal. 1939).

71. SEC v. Evergreen Memorial Park Ass'n, Civil Nos. 24, 424, E.D. Pa., April 11, 1958; SEC v. Adams Bond \& Share, Inc., Civil No. 3413, D. Idaho, Feb. 13, 1958; SEC v. Insurance Corp. of America, Civil No. IP-56-C-152, S.D. Ind., June 13, 1957; SEC v. Mitchell Securities, Inc., Civil No. 8860, D. Md., May 16, 1956; SEC v. Errion, Civil No. 7115, D. Ore., Nov. 20, 1953; SEC v. United Insurers Serv. Co., Civil No. 7219, W.D. Mo., Nov. 16, 1951; SEC v. Orler, Civil No. 725, D. Mass., Sept. 27, 1940; SEC v. Associated Pharmacists, Inc., Civil No. 2493, D. Md., April 26, 1937; SEC v. Bond \& Share Co., Civil No. 5631, N.D. Ohio, Aug. 11 and Sept. 9, 1937; SEC v. Hickox Fin. Corp., Civil No. 5613, N.D. Ohio, June 24, 1937.

72. Supra note 71.

73. SEC v. Evergreen Memorial Park Ass'n, Civil No. 11821, E.D. Pa., 1953.

74. It omitted any significant financial information concerning the company; it said nothing of the previous decree in the federal court and of its failure to comply therewith; it failed to state that the delinquency in the perpetual care fund had increased substantially; and it omitted to show that Evergreen had no active sales force to sell the cemetery lots, or that it had an operating deficit in excess of $\$ 200,000$. 
later block of debentures had been sold, the Commission brought a second action. Being on notice of possible action by the Commission, Evergreen endeavored to raise additional funds by giving personal notes for amounts to be invested in the company. All of these activities were the subject of the Commission's injunctive action.

After an unsuccessful attempt to obtain dismissal of the Commission's complaint, Evergreen agreed to the entry of a final injunctive decree. As late as the actual hearing for preliminary injunction, however, it contended that if it had violated any statute it was the Pennsylvania act rather than the Federal Securities Act. ${ }^{75}$

This graphically depicts a misconception which is doubtlessly widespread. The applicability of the anti-fraud provisions of the Securities Act to intrastate sales, despite the intrastate exemption from registration, is perhaps one of the most misunderstood facets of the act. Although the Commission has not in fact, during the past twenty-five years, brought an exceptionally high number of injunctive actions to restrain intrastate issuers from violations of section 17 , the Commission's more recent emphasis upon enforcement action makes it reasonable to predict that a great many more injunctive actions will be brought in section 3(a) (11) cases in the years immediately ahead. In addition, of course, there is also the possibility, if not the likelihood, that the Commission will refer more and more intrastate fraud cases to the Attorney General for criminal prosecution. ${ }^{76}$

\section{Civil Liability}

Similar misconception may exist with regard to the civil liability provisions of the act. But under section 12(2) a person who offers or sells a security, even though exempt from registration under section

75. Following the SEC action a receiver was appointed for Evergreen in the Common Pleas Court of Philadelphia and, thereafter, the company was placed in bankruptcy (E.D. Pa. Bankruptcy Cause No. 25731, pending). A report of the receiver shows liabilities in excess of $\$ 1,400,000$ against the cemetery property (now valued for other than cemetery purposes at $\$ 100,000)$ and other property and receivables of $\$ 20,000$. Evergreen's bank account contained $\$ 5.09$.

76. Commission Litigation Releases which disclose recent criminal referrals in intrastate fraud prosecutions are: Litigation Release No. 1414 (1959) (four defendants); Litigation Release No. 1203 (1958) (two defendants); Litigation Release No. 1152 (1957) (sevent defendants); Litigation Release No. 1151 (1957) (four defendants); and Litigation Release No. 1128 (1957) (seven defendants). These referrals cover twenty defendants. Since the Commission does issue a release until an indictment has been returned, these releases do not cover intrastate fraud cases which have been referred to the Justice Department but which have not yet been acted upon. Further indication of the breadth of the Commission's activities with respect to violations of the intrastate exemption is that Chairman Edward N. Gadsby announced to the Congress that in 1957 and 1958 the SEC opened 115 investigations of offerings claimed to be exempt under $\$ 3(\mathrm{a})(11)$. Statement Before a Subcommittee on Commerce and Finance of the House Committee on Interstate and Foreign Commerce 15 (March 24, 1959). 
3 (a) (11), may incur a civil liability to the purchaser. $^{77}$ Conditions precedent to the imposition of liability in connection with an offer or sale are: (1) use of interstate facilities or of the mails, ${ }^{78}$ (2) use of a prospectus $^{79}$ or oral communication, (3) the making of an untrue statement or the omission to state material facts thus rendering the statements made misleading (either in the prospectus or oral communication), and (4) absence of knowledge by the purchaser of the untruth or omission. As a defense under the act the person selling the security has the burden of proving that he did not know, and in the exercise of reasonable care could not have known, of the untruth or omission..$^{80}$ The liability on the seller is not absolute; it is based upon knowledge or, in the alternative, the failure to exercise due care. ${ }^{81}$

\section{State Securities Regulation}

The securities industry is regulated internally on a voluntary basis by the National Association of Securities Dealers. ${ }^{82}$ External, involuntary regulation is in the hands of the SEC (except for margin requirements set by the Federal Reserve Board) ${ }^{83}$ and the various states. As a result, there is a myriad of rules and regulations applicable to broker-dealers and to issuers of securities. However, even the com-

77. 48 Stat. 84 (1933), 15 U.S.C. $\$ 77 l(2)$ (Supp. V, 1958). The liability is not limited to the issuer. It extends to a broker who sells securities as an agent on behalf of an issuer, Cady v. Murphy, 113 F.2d 988 (1st Cir. 1940), and to an officer and director who sells, Stadia Oil \& Uranium Co. v. Wheelis, 251 F.2d 269 (10th Cir. 1957). It appears from the statutory language that any person who sells for an issuer, regardless of his relationship, is within the orbit of potential liability.

78. Civil liability may be imposed even though the use of the mails has been confined solely to one state: Deckert v. Independence Shares Corp., 39 F. Supp. 592 (E.D. Pa 1941) ; Gross v. Independence Shares Corp., 36 F. Supp. 541 (E.D. Pa. 1941). The use of the jurisdictional means in any part of the transaction is sufficient. It is not necessary that they be used in the communication of the untrue statement or with respect to the omissions. A delivery of the security or payment thereof by mail will suffice: Cresweil-Keith, Inc. v. Willingham, 264 F.2d 76 (8th Cir. 1959); Blackwell v. Bentsen, 203 F.2d 690 (5th Cir.), cert. granted, 346 U.S. 908 (1953), cert. dismissed, 347 U.S. 925 (1954); Schillner v. H. Vaughn Clarke \& Co., 134 F.2d 875 (2d Cir. 1943); as will a delivery by an interstate railroad: Moore v. Gorman, 75 F. Supp. 453 (S.D.N.Y. 1948).

79. "Prospectus" is defined in $\$ 2(10), 48$ Stat. 75 (1933), as amended, 15 U.S.C. $\S 77 \mathrm{~b}(10)$ (Supp. V, 1958). It is not limited to the formal, bulky document filed with the Commission; it includes letters, circulars and advertisements which appear in newspapers and on radio and television. Communications not deemed to be a prospectus are covered in Commission rule 134, 17 C.F.R. 230.134 (Supp. 1958).

80. The basis for shifting the burden to the seller is based upon the congressional opinion that the seller is in the best position to know of any flaw in the selling statements. H.R. REP. No. 85 , supra note 16 , at 23 . The common-law burden of reasonable care is shifted from the buyer to the seller. Murphy v. Cady, $30 \mathrm{~F}$. Supp. 466 (S.D. Me 1939), aff'd, Cady v. Murphy, 113 F.2d 988 (1st Cir. 1940).

81. Petersen Engine Co., 2 S.E.C. 893 (1937).

82. The Association (hereinafter referred to as the N.A.S.D.) exists pursuant to the Meloney Act $\$ 15 \mathrm{~A}$ amendment to the Securities Exchange Act, 52 Stat. 1070 (1938), 15 U.S.C. \$78o-3 (1952).

83. Exchange Act $\$ 7,48$ Stat. 886 (1934), as amended, 15 U.S.C. $\$ 78 g$ (1952). 
bined efforts over the past two-and-one-half decades of all of these regulatory bodies have not effectuated an eradication of fraudulent or other undesirable practices which result in the loss every year of many millions of dollars by the investing public.

Among the serious and usually complicated enforcement problems confronting the several securities regulatory bodies are: (1) the "boiler rooms," which usually sell securities through fraudulent and deceptive high pressure methods by use of the long-distance telephone; (2) the corporate "empire builders," who, through mergers, proxy raids, acquisitions of subsidiaries and the like, create fictitious market values in the securities of the company involved; (3) the manipulators, who put "packages" together for others, supply needed capital or sources of capital, jiggle the prices of stocks, proffer investment advice (all for a consideration, usually stock), and who, when the bubble bursts, probably make a secondary profit either by foreseeing the end or by setting the date for it, having sold "short" at the right time; (4) the plain, ordinary "con men," who live by their wits, the gullibility of the public, and the "get-rich-quick" aspirations of the average public investor; and (5) the bumbling optimists, who are so bent upon putting through "their deal" (always convinced that they have finally found the "better mousetrap") that they ignore the plain requirements of the law as to fraud. Most public investors who purchase securities which have been offered for sale through the hands of any of these persons are apt to suffer substantial financial losses.

The activities of boiler rooms, corporate empire builders and manipulators are not usually confined to a single state. Therefore, effective enforcement against them depends upon the Commission, the national securities exchanges, or the N.A.S.D. On the other hand, state authorities, in addition, can be effective in enforcing the law against con men and fraudulent promoters. It is these latter two types of activity which can and do flourish within the boundaries of a single state.

The only really effective method of handling these enforcement problems, either by the states or the federal government, is through criminal prosecution. Civil action, by way of a court injunction, may stop a particular aspect of one of these problems, but an injunction, which has only latent punitive effects, is not an effective deterrent. Further, since the disclosure provisions of the Securities Act are directed primarily to new issues of securities those provisions are not a satisfactory answer to the serious enforcement problems set forth above. In those states in which the state commission or the administrator exercises a power to prohibit the sale of certain new issues of securities 
or to impose conditions thereon, investors have at least a greater measure of protection than investors in other states. ${ }^{84}$ However, this paternalistic "spoon-feeding" of public investors does not begin to cope with the major enforcement problems.

Today, state securities regulation follows no uniform pattern. Aside from the fact that neither Nevada nor Delaware has any "bluesky" law at all, the remaining state statutes are an almost hopeless hodge-podge. Some have only fraud statutes, others register or qualify securities, while still others register or license persons engaged in securities transactions. Mostly, the states have combined two or more of these. In any event, however, regardless of the particular pattern adopted, there are as many variances in statutory language, section by section, as there are state laws. ${ }^{85}$ To this situation which is so desperately in need of correction, there are two possible solutions. One would be the adoption of a uniform statute. The other, the route of Representative Multer's proposal, ${ }^{86}$ is that the federal government pre-empt the field.

Because of the varying philosophies of the existing state securities laws, a project to recommend one integrated uniform act was abandoned in favor of a proposed uniform act containing provisions in four separable areas: i.e., (1) anti-fraud, (2) registration of broker-dealers, salesmen and investment advisers, (3) registration of securities, and (4) general provisions to implement the first three. This permits a state to adopt one or more of the severable portions of the act. To date the uniform act has received only modest acceptance, despite the widespread approval which has been accorded to it by industry, the bar and the North American Securities Administrators. ${ }^{87}$

The second alternative, that the federal government pre-empt the field, is based upon the premise that uniform state laws are not an adequate solution because in this area the states no longer perform an

84. There is a sharp difference in theoretical approach between the full disclosure provisions of the Securities Act and these particular state statutes. When one considers (1) the impact of these state laws on the economy of the country and the capital markets in general, (2) the great power which they vest in, and which may be exercised at the whim of, the state authority, and (3) the lack of uniformity which necessarily results from such ad hoc administration-and weigh these against the investor protections which result-it appears that on balance the disclosure theory, if supported by aggressive anti-fraud enforcement, is more sound.

85. Loss \& Cowetr, BluE SkY LAw (1958), is a comprehensive study of the field.

86. See notes 57-59 supra and accompanying text.

87. For text and coment on the Uniform Securities Act see Loss \& CowETT, BLuE Sky LAw 245-420 (1958). This text also sets forth a summary of the developments leading up to the adoption of the final draft, and a report showing what actions certain states have taken with respect to the act. Loss \& CowET, op. cit. supra 233-36. 
important social or economic function. ${ }^{88}$ It goes without saying that for numerous, varied reasons there are many who controvert this position. There are literally thousands of securities offerings made every year by issuers who distribute them exclusively intrastate. Some may involve large amounts of money, but the very great majority of such intrastate distributions probably involve less than $\$ 100,000$. Thus, to effect federal pre-emption by elimination of the intrastate exemption of section 3(a) (11) would inject the Commission into the financing of every small business in the country. It might be argued that offerings under a certain amount, e.g., $\$ 100,000$, could be excluded. This is not really a sound logical alternative, however, because there is just as much need for disclosure in a $\$ 50,000$ offering as there is in one of $\$ 150,000$.

In the author's view, the original congressional policy of reserving to the states jurisdiction over the securities industry is as sound today as it was twenty-five years ago. There is much to be said for the proposition that the local financing of local business should be supervised by local authority. If this policy were supported in the states by the adoption of the Uniform Securities Act, many of the current difficulties would be eased, if not eliminated. The registration provisions of the uniform act would require necessary disclosures not presently being made in many states. But adequate regulation will not result unless the states adopt the entire uniform act. The securities industry and bar would do well to continue to urge that view. Of course, the states must make necessary budgetary allowances to support the enforcement of the law.

There is another area of regulation where the states, rather than the federal government, are probably best able to do the job and that is in the registration and control of securities salesmen. The Commission does not have statutory authority to register salesmen; the statutory power covers only broker-dealers. ${ }^{89}$ Aside from that, this

88. Armstrong, Comment-The Blue Sky Lazes, 44 VA. L. REv. 713 (1958). It is impossible to summarize here the many arguments stated in support of the position taken by Mr. Armstrong. It is believed, however, that the following two statements are representative of why he favors federal pre-emption. "This tremendous, sensitive, complex mechanism of the corporate securities markets is extremely important to our national economy. It is this national, as opposed to local or single-state economy, which should concern us." Id. at 717. "Thus the states, exercising their sovereign police power in an economic area of interstate significance, have distorted their original purpose to protect their citizens against fraud. Instead they have set up a protective machinery, often based on local interests, which is completely antithetical to the public interest in free and open corporate securities markets. The Uniform Act does not appear to offer a solution to this." Id. at 718.

89. Exchange Act $\$ 15(a), 48$ Stat. 895 (1934), as amended, 15 U.S.C. $\$ 780$ (1952). See SEC v. Wallach, 202 F.2d 462 (D.C. Cir. 1953). 
type of regulation appears to be one which can be best handled locally by state authorities.

\section{CONCLUSION}

With both state and federal laws applicable in certain respects to intrastate offerings and sales of securities, issuers and their counsel must take notice that:

1. In every state the anti-fraud and civil liability provisions of the federal law apply;

2. In states which themselves have statutes with anti-fraud provisions, an issuer or other seller of securities may, by his misconduct, subject himself to both state and federal criminal or civil sanctions; and

3. In many intrastate offerings of securities difficult interpretive problems may arise as a result of which the intrastate exemption may be nullified and registration of the securities under federal law may become necessary.

In short, the intrastate exemption is a limited one; much more so than most issuers realize. The exemption rests upon the foundation laid in section 18 of the act wherein Congress preserved the jurisdiction of the states over transactions in securities. The legislative history of the Securities Act clearly outlines the respective roles of the federal and state securities authorities in regulating traffic in this intricate merchandise. It is most unfortunate that in the past quarter-century the states, which were the pioneers in this regulatory field, have not demonstrated the foresight and aggressive leadership which marked their early efforts to protect public investors.

Today, state authorities generally have neither adequate statutory tools with which to work nor sufficient budgetary allowances to employ the staff personnel necessary to do the interpretive, regulatory, and enforcing jobs which must be done. As a result of the appalling lack of uniformity among the laws of the various states, legitimate businesses are confronted by unnecessary and costly barriers to their public financing. For the same reason purveyors of worthless or questionable securities may pick and choose the states on which they will descend to take unfair advantage of a gullible and unsuspecting public. It is no answer figuratively to collect all intrastate securities offerings in one bundle and to deposit them on the doorstep of the SEC. The real answer lies in a revival of the vigorous leadership which the states originally demonstrated in this field. Strong state legislation, properly and adequately administered, and, at the same time, supplemental fed- 
eral legislation is the same prescription which Congress wrote out twenty-five years ago. Already the biggest part of the job has been done for the states. The Uniform Securities Act has been drafted; it is an excellent working tool. It need only be adopted. Were all states to adopt the complete uniform act and to supplement it with adequate budgets, each state would be doing its share by protecting its proportion of our eight million public investors. In the past five years the program has been accorded a full measure of lip-service. On its merits it is entitled to more-from industry, the organized bar, the financial community and the securities authorities themselves. 